ХОВПУН О.С.

\title{
ОСОБЛИВОСТІ ЗДІЙСНЕННЯ ДЕРЖАВНОГО УПРАВЛІННЯ У ФАРМАЦЕВТИЧНІЙ СФЕРІ УКРАЇНИ
}

У статті розглянуто особливості здійснення державного управління у сфері створення, виробництва, контролю якості та реалізації лікарських засобів в Україні. Проаналізовано розвиток фармацевтичного ринку України та діяльність суб'єктів підприємницької діяльності у цій сфері.

Зазначено, що в Україні існує багаторівнева система державного управління у сфері створення, виробництва, контролю якості та реалізації лікарських засобів. Проаналізовано основні повноваження Верховної Ради України, Кабінету Міністрів України, Міністерства охорони здоров'я України, Державної служби України з лікарських засобів та контролю за наркотиками, Антимонопольного комітету України у сфері створення, виробництва, контролю якості та реалізації лікарських засобів. Зазначено, що саме у процесі реалізації державної політики у сфері виробництва та реалізації лікарських засобів важливу роль у державному управлінні відіграють Міністерство охорони здоров’я України та Держлікслужба. Саме ці органи державної влади здійснюють ліцензування діяльності з виробництва лікарських засобів, ліцензування оптової та роздрібної торгівлі лікарськими засобами, реєстрацію лікарських засобів, сертифікацію лікарських засобів, створення системи стандартизації і державного контролю виробництва, виготовлення, реалізації, якості лікарських засобів.

Зроблено висновок, що розвиток ринку фармацевтичної промисловості зумовлює необхідність удосконалення діючої системи державного управління. Органи державної влади й надалі повинні вживати заходів для забезпечення дієвого контролю за виробництвом та реалізацією лікарських засобів, упровадження сучасних методів запобігання фальсифікації лікарських засобів, систематичним здійсненням моніторингу. Лише взаємодія і злагоджена робота органів державної влади надасть можливість досягнути міжнародного рівня регулювання відносин у фармацевтичній сфері.

Ключові слова: державне управління, державна політика, органи держсавноі влади, виробництво лікарських засобів, контроль якості лікарських засобів, реалізаиія лікарських засобів.

In the article the peculiarities of realization of state governance in the sphere of creation, production, quality control and sale of medicines in Ukraine are presented. The development of the pharmaceutical market of Ukraine and business entities of activities in this area is analysed.

It is noted that in Ukraine there is a multi-level system of state governance in the sphere of creation, production, quality control and sale of medicines. The basic powers of the Verkhovna Rada of Ukraine, the Cabinet of Ministers of Ukraine, the Ministry of Health of Ukraine, the State Service of Ukraine for Medicines and Drug Control, the Antimonopoly Committee of Ukraine in the sphere of creation, production, quality control and sale of medicines are analysed. It is noted that the Ministry of Health of Ukraine and the State Service of Ukraine for Medicines and Drug Control play an important role in state governance in the process of implementation of the state policy in the sphere of production and sale of medicines. These state authorities carry out licensing of activity of drug production, licensing of wholesale and retail trade of medicines, registration of medicines, certification of medicines, creation of a system of standardization and state control over the production, manufacture, marketing and quality medicines.

(C) ХОВПУН О.С. - кандидат юридичних наук, доцент, завідувач кафедри кримінального права, процесу та криміналістики (Академія праці, соціальних відносин і туризму) 
It is concluded that the development of the market of the pharmaceutical industry determines the need of improving the current system of state governance. Public authorities should continue to take measures to ensure effective control over the production and sales of medicines, the introduction of modern methods of preventing the falsification of medicines, and the systematic implementation of monitoring. Only the interaction and coordinated work of public authorities will provide an opportunity to reach the international level of regulation in the pharmaceutical sphere.

Key words: state governance, public policy, public authorities, production of medicines, quality control of medicines, sales of medicines.

Вступ. Фармацевтична галузь у світі прогресивно розвивається, і сьогодні це $є$ особливий сегмент ринку, який потребує суворого державного регулювання та управління. В Україні фармацевтична галузь теж динамічно розвивається та посідає значне місце в національній економіці. Недивлячись на те, що частка світового експорту фармацевтичної продукції, яка виготовлена в Україні, становить лише $0,05 \%$ світового експорту [1], у 2019 році експорт фармацевтичної продукції збільшився на 29,5 мільйонів доларів порівняно із 2018 роком [2]. Розвиток фармацевтичного ринку в Україні створює необхідність здійснення дієвого державного управління у сфері створення, виробництва, контролю якості та реалізації лікарських засобів.

Питання державного управління у фармацевтичній сфері є не новим і досліджувалося багатьма вченими, зокрема: С.В. Васильєвим, Н.В. Волк, В.В. Лазарєвим, О.П. Світличним, Л.М. Руснак, В.І. Теремецьким. Утім, через глобалізацію фармацевтичного ринку та прагнення України бути рівноправним членом у світовій торгівлі існує об'єктивна необхідність подальших досліджень цієї сфери.

Постановка завдання. Метою статті є висвітлення особливостей державного управління у сфері створення, виробництва, контролю якості та реалізації лікарських засобів в Україні.

Результати дослідження. Процес створення, виробництва, контролю якості та реалізації лікарських засобів являє собою складний процес, який охоплює одну або декілька операцій щодо технологічного процесу (змішування, грануляція, фрезерування, покриття, пресування таблеток, наповнення), контролю якості, видачі дозволу на випуск, закупівлю матеріалів і продукції. Крім того, цей процес пов'язаний із зберіганням, постачанням, забезпеченням якості на всіх ділянках ланцюга постачання від виробника до аптеки або лікувально-профілактичного закладу, транспортуванням, оптовою чи роздрібною торгівлею, імпортом чи експортом лікарських засобів [3]. Процес виробництва і реалізації лікарських засобів відзначається великою кількістю учасників: виробники лікарських засобів, представники або дистриб'ютори виробників лікарських засобів, суб'єкти підприємницької діяльності, які здійснюють оптову та роздрібну торгівлю лікарськими засобами, споживачі лікарських засобів. Станом на кінець 2019 року в Україні налічується 113 суб'єктів підприємницької діяльності, які займаються промисловим виробництвом лікарських засобів, 401 суб'єкт підприємницької діяльності, що займаються оптовою торгівлею лікарськими засобами, 6455 суб'єктів підприємницької діяльності (з них 17475 - аптеки, 4399 - аптечні пункти), які займаються роздрібною торгівлею лікарських засобів; 41 суб'єкт підприємницької діяльності, що займаються промисловим виробництвом обігу наркотичних засобів, психотропних речовині прекурсорів [4].

Наявність значної кількості суб'єктів підприємницької діяльності, які займаються виробництвом та реалізацією лікарських засобів, зумовлює підвищення ефективності державного управління, що покликано забезпечити впровадження та реалізацію політики у фармацевтичній сфері. Потрібно, щоб лікарські засоби вироблялися й реалізовувались відповідно до вимог чинного законодавства України та положень міжнародних актів щодо міжнародних стандартів системи забезпечення якості продукції та послуг (належної виробничої практики, належної клінічної практики, належної лабораторної практики, належної практики з фармаконагляду), а органами державної влади - здійснювався б дієвий контроль за фармацевтичною діяльністю на кожному етапі виробництва, реєстрації та реалізації лікарських засобів.

В основі державної політики у сфері створення, виробництва, контролю якості та реалізації лікарських засобів лежить реалізації права громадян України на охорону здоров'я, адже людина, її життя і здоров'я визнається в Україні найвищою соціальною цінністю [5]. 3 метою реалізації права громадян України на охорону здоров'я держава забезпечує доступність найнеобхідніших лікарських засобів, захист громадян у разі заподіяння шкоди їх здоров'ю внаслідок за- 
стосування лікарських засобів за медичним призначенням, а також установлює пільги й гарантії окремим групам населення та категоріям громадян щодо забезпечення їх лікарськими засобами в разі захворювання.

Державна політика у сфері створення, виробництва, контролю якості та реалізації лікарських засобів спрямовується на підтримку наукових досліджень, на створення та впровадження нових технологій, а також на розвиток виробництва високоефективних та безпечних лікарських засобів, задоволення потреб населення ліками належної якості та в необхідному асортименті шляхом ведення Державного реєстру лікарських засобів України із забезпеченням публічного доступу до нього осіб, здійснення відповідних загальнодержавних програм, пріоритетного фінансування, надання пільгових кредитів, установлення податкових пільг тощо [6].

Сьогодні в Україні запроваджено багаторівневу систему державного управління у сфері створення, виробництва, контролю якості та реалізації лікарських засобів. Відповідно до статті 4 Закону України «Про лікарські засоби», державне управління у сфері створення, виробництва, контролю якості та реалізації лікарських засобів здійснюють Верховна Рада України (ВРУ), Кабінет Міністрів України (КМУ), Міністерство охорони здоров’я України (МОЗ України), Державна служба України з лікарських засобів та контролю за наркотиками (Держлікслужба) та їх територіальні підрозділи [6].

ВРУ визначає державну політику і здійснює законодавче регулювання відносин у сфері створення, виробництва, контролю якості та реалізації лікарських засобів. Так, прийнятий ВРУ Закон України «Про лікарські засоби» регулює правовідносини, пов'язані зі створенням, реєстрацією, виробництвом, контролем якості та реалізацією лікарських засобів, визначає права та обов'язки підприємств, установ, організацій і громадян, а також повноваження у цій сфері органів виконавчої влади й посадових осіб [6]. У Законі України «Про ліцензування видів господарської діяльності» визначено, що виробництво лікарських засобів підлягає ліцензуванню як засіб державного регулювання провадження господарської діяльності, спрямований на гарантію безпеки та захисту економічних і соціальних інтересів держави, суспільства, прав та законних інтересів, життя і здоров'я людини, екологічної безпеки та охорони довкілля [7].

КМУ забезпечує проведення політики у сфері охорони здоров’я [8]. Саме через систему органів виконавчої влади КМУ втілює в життя державну політику у сфері створення, виробництва, контролю якості та реалізації лікарських засобів, організовує розробку та здійснення відповідних загальнодержавних та інших програм у межах своїх повноважень, забезпечує контроль за виконанням законодавства про лікарські засоби [6]. Так, у постанові КМУ «Про затвердження Державної стратегії реалізації державної політики забезпечення населення лікарськими засобами на період до 2025 року» основними завданнями у сфері фармацевтичної діяльності визначено такі:

- удосконалення державного регулювання та забезпечення якості лікарських засобів;

- удосконалення системи постачання лікарських засобів;

- підвищення інвестиційної привабливості фармацевтичного ринку України у сфері розробки та дослідження лікарських засобів [9].

Постановою КМУ «Про затвердження Ліцензійних умов провадження господарської діяльності з виробництва лікарських засобів, оптової та роздрібної торгівлі лікарськими засобами, імпорту лікарських засобів (крім активних фармацевтичних інгредієнтів)» сформульовано вичерпний перелік вимог, обов'язкових для виконання ліцензіатом, та вичерпний перелік документів, які додаються до заяви про отримання ліцензії для провадження господарської діяльності 3 виробництва лікарських засобів, оптової, роздрібної торгівлі лікарськими засобами, імпорту лікарських засобів (крім активних фармацевтичних інгредієнтів) [10].

До органів виконавчої влади, що здійснюють державне управління у сфері створення, виробництва, контролю якості та реалізації лікарських засобів у межах своєї компетенції, належать MO3 та Держлікслужба.

MO3 є головним органом у системі центральних органів виконавчої влади, яке забезпечує формування та реалізує державну політику у сфері охорони здоров'я. Саме МОЗ забезпечує формування та реалізує державну політику у сфері створення, виробництва, контролю якості та реалізації лікарських засобів, медичних імунобіологічних препаратів, обігу наркотичних засобів, психотропних речовин, їх аналогів і прекурсорів, протидії їх незаконному обігу, а також безпечних медичних виробів та косметичної продукції.

MO3 має значні повноваження у сфері створення, виробництва, контролю якості та реалізації лікарських засобів. Зокрема, МОЗ затверджує методи здійснення контролю якості лікарського засобу; порядок перевірки суб'єктів господарювання та здійснення контролю якості 
лікарських засобів; порядок здійснення контролю якості лікарських засобів під час оптової та роздрібної торгівлі; порядок здійснення фармаконагляду; порядок організації та проведення експертизи, а також узгодження нормативно-технічної документації з виробництва лікарських засобів; порядок проведення клінічних випробувань лікарських засобів та експертизи матеріалів клінічних випробувань; порядок проведення сертифікації виробництва лікарських засобів, лікарських засобів для міжнародної торгівлі, а також сертифікації підприємств, які здійснюють оптову реалізацію (дистрибуцію) лікарських засобів; правила виробництва та контролю якості лікарських засобів в аптеках тощо [11].

MO3 України видало чимало наказів для регулювання цієї сфери («Про затвердження Порядку проведення галузевої атестації лабораторій з контролю якості та безпеки лікарських засобів» [12], «Про затвердження Порядку сертифікації якості лікарських засобів для міжнародної торгівлі та підтвердження для активних фармацевтичних інгредієнтів, що експортуються»[13], «Про затвердження Порядку контролю якості лікарських засобів під час оптової та роздрібної торгівлі» [14] тощо). Крім того, МОЗ здійснює державну реєстрацію (перереєстрацію) лікарських засобів, затверджує декларовані зміни оптово-відпускних цін на лікарські засоби, які закуповуються за кошти державного та місцевих бюджетів; приймає в установленому порядку рішення про проведення клінічних випробувань лікарських засобів та їх припинення; веде Державний реєстр лікарських засобів; виконує функції технічного регулювання у сфері охорони здоров'я, створення, виробництва, контролю якості та реалізації лікарських засобів [11].

Держлікслужба є центральним органом виконавчої влади, діяльність якого спрямовується і координується КМУ через Міністра охорони здоров'я, який реалізує державну політику у сферах контролю якості та безпеки лікарських засобів, у тому числі медичних імунобіологічних препаратів, медичної техніки й виробів медичного призначення, та обігу наркотичних засобів, психотропних речовин і прекурсорів, протидії їх незаконному обігу. Основними завданнями Держлікслужба є: реалізація державної політики у сферах контролю якості та безпеки лікарських засобів, медичних виробів та обігу наркотичних засобів, психотропних речовин і прекурсорів, протидії їх незаконному обігу, а також внесення Міністрові охорони здоров'я пропозицій щодо формування державної політики у зазначених сферах; ліцензування господарської діяльності з виробництва лікарських засобів, імпорту лікарських засобів (крім активних фармацевтичних інгредієнтів), оптової та роздрібної торгівлі лікарськими засобами, обігу наркотичних засобів, психотропних речовин і прекурсорів; технічне регулювання у визначених сферах; здійснення державного регулювання й контролю у сферах обігу наркотичних засобів, психотропних речовин і прекурсорів та протидії їх незаконному обігу [15]. Саме Держлікслужба формує й веде реєстр документів щодо якості лікарських засобів, ліцензійний реєстр із виробництва лікарських засобів (в умовах аптеки), оптової та роздрібної торгівлі лікарськими засобами, ліцензійний реєстр із промислового виробництва лікарських засобів, ліцензійний реєстр з імпорту лікарських засобів, реєстр ліцензій на провадження діяльності з виробництва (виготовлення) лікарських засобів (в умовах аптеки), оптової та роздрібної торгівлі лікарськими засобами, дія яких зупинена повністю або частково, ліцензійний реєстр на право здійснення господарської діяльності з обігу наркотичних засобів, психотропних речовин і прекурсорів [16].

Крім того, саме Держлікслужба здійснює державний контроль за дотриманням вимог законодавства щодо забезпечення якості та гарантії безпеки лікарських засобів на всіх етапах обігу, в тому числі правил здійснення належних практик (виробничої, дистриб'юторської, зберігання, аптечної); здійснює контроль за дотриманням суб'єктами господарювання ліцензійних умов провадження господарської діяльності з виробництва лікарських засобів, імпорту лікарських засобів (крім активних фармацевтичних інгредієнтів), оптової та роздрібної торгівлі лікарськими засобами; складає протоколи про адміністративні правопорушення та розглядає справи про адміністративні правопорушення в передбачених законом випадках; приймає в установленому порядку рішення про вилучення з обігу та заборону (зупинення) виробництва, реалізації та застосування лікарських засобів і медичних виробів, які не відповідають вимогам, визначеним нормативно-правовими актами, а також тих, що ввозяться на територію України та вивозяться 3 території України з порушенням установленого законодавством порядку тощо [15; 17]. Так, протягом 2019 року Держлікслужбою проведено 1215 планових перевірок ліцензіатів фармацевтичної практики та 324 позапланових перевірки дотримання вимог законодавства щодо якості лікарських засобів ліцензіатами фармацевтичної практики. За результатами таких перевірок установлено 2453 порушення вимог законодавства щодо якості лікарських засобів під час планових заходів ліцензіатів фармпрактики та видано 1034 розпорядження/приписи про усунен- 
ня порушень; відібрано 1917 зразків лікарських засобів (ЛЗ) на лабораторний аналіз; складено 432 адміністративних протоколи за вчинення адміністративних правопорушень [4].

Отже, саме MO3 та Держлікслужба відіграють найважливішу роль у державному управлінні, здійснюючи ліцензування діяльності з виробництва лікарських засобів, ліцензування оптової та роздрібної торгівлі лікарськими засобами, реєстрацію та сертифікацію лікарських засобів, створюють системи стандартизації і державного контролю виробництва, виготовлення, реалізації, якості лікарських засобів тощо.

Крім того, важливу роль у державному управлінні у сфері реалізації лікарських засобів відіграє Антимонопольний комітет України, який є державним органом із спеціальним статусом, метою діяльності якого є забезпечення державного захисту конкуренції в підприємницькій діяльності та у сфері державних закупівель. Антимонопольний комітет України здійснює державний контроль за дотриманням законодавства про захист економічної конкуренції, запобігає, виявляє і припиняє порушення законодавства про захист економічної конкуренції у фармацевтичній сфері; контролює за концентрацією, узгодженими діями суб'єктів господарювання та дотриманням вимог законодавства про захист економічної конкуренції під час регулювання цін (тарифів) на товари, які виробляються (реалізуються) суб'єктами природних монополій; сприяє розвитку добросовісної конкуренції; здійснює контроль за створенням конкурентного середовища та захистом конкуренції у сфері державних закупівель, що пов'язано з фармацевтичною діяльністю тощо [18].

Висновки. Державне управління у сфері створення, виробництва, контролю за якістю та реалізацією лікарських засобів здійснюється органами законодавчої та виконавчої влади. ВРУ визначає державну політику і здійснює законодавче регулювання відносин у сфері створення, виробництва, контролю якості та реалізації лікарських засобів. Саме КМУ, МОЗ, Держлікслужба, Антимонопольний комітет України та їх територіальні підрозділи забезпечують реалізацію державної політики у сфері створення, виробництва, контролю за якістю та реалізацією лікарських засобів. Водночас розвиток ринку фармацевтичної промисловості зумовлює необхідність удосконалення нинішньої системи державного управління. Органи державної влади й надалі повинні вживати заходів для забезпечення дієвого контролю за виробництвом та реалізацією лікарських засобів, упроваджувати сучасні методи запобігання фальсифікації лікарських засобів, систематично здійснювати моніторинг. Лише взаємодія і злагоджена робота органів державної влади надасть можливість досягнути міжнародного рівня регулювання відносин у фармацевтичній сфері. Перспективним у подальшому $є$ наукова розробка питань, пов'язаних із запровадженням дієвої системи моніторингу за діяльністю суб'єктів підприємницької діяльності в цій сфері, впровадження державно-приватного партнерства, розгляду питання взаємодії органів виконавчої влади із громадськими організаціями, які діють у сфері фармації та розвивають фармацевтичну діяльність.

\section{Список використаних джерел:}

1. Trade map. List of importing markets for the product exported by Ukraine in 2019 (Mirror) Product: 30 Pharmaceutical products. URL: https://www.trademap.org/Country_SelProductCountry.as px?nvpm $=1 \% 7 \mathrm{c} 804 \% 7 \mathrm{c} \% 7 \mathrm{c} \% 7 \mathrm{c} \% 7 \mathrm{c} 30 \% 7 \mathrm{c} \% 7 \mathrm{c} \% 7 \mathrm{c} 2 \% 7 \mathrm{c} 1 \% 7 \mathrm{c} 2 \% 7 \mathrm{c} 2 \% 7 \mathrm{c} 1 \% 7 \mathrm{c} 1 \% 7 \mathrm{c} 2 \% 7 \mathrm{c} 1 \% 7 \mathrm{c} 1$ (дата звернення: 27.12.2019 р.).

2. Зовнішня торгівля України товарами у січні-жовтні 2019 року. Довідка. Міністерство розвитку економіки, торгівлі та сільського господарства Украӥни. URL: https://www.me.gov.ua/ Documents/Detail?lang=uk-UA\&id=81260d33-6a7d-4c34-9d4a-6e333100b246\&title=Dovidkazovnis hniaTorgivliaUkrainiTovaramiUSichnizhovtni2019-Roku (дата звернення: 26.12.2019р.).

3. Про затвердження Ліцензійних умов провадження господарської діяльності з виробництва лікарських засобів, оптової та роздрібної торгівлі лікарськими засобами, імпорту лікарських засобів (крім активних фармацевтичних інгредієнтів) : постанова Кабінету Міністрів України від 30.11.2016 № 929. URL: https://zakon.rada.gov.ua/laws/show/929-2016-\%D0\%BF (дата звернення: 27.12.2019 p.).

4. Звіт про підсумки діяльності Державної служби України з лікарських засобів та контролю за наркотиками у 2019 році. URL: https://www.kmu.gov.ua/news/21-lyutogo-2020-rokuvidbudetsya-publichnij-zvit-golovi-derzhavnoyi-sluzhbi-ukrayini-z-likarskih-zasobiv-ta-kontrolyu-zanarkotikami (дата звернення: 26.12.2019 р.).

5. Конституція України від 28.06.1996 № 254к/96-BP. URL: https://zakon.rada.gov.ua/laws/ show $/ 254 \% \mathrm{D} 0 \% \mathrm{BA} / 96-\% \mathrm{D} 0 \% \mathrm{~B} 2 \% \mathrm{D} 1 \% 80$ (дата звернення: 27.12 .2019 р.). 
6. Про лікарські засоби : Закон України від 04.04.1996 № 123/96-BP. URL: https://zakon.rada.gov.ua/laws/show/123/96-\%D0\%B2\%D1\%80 (дата звернення: 27.12.2019р.).

7. Про ліцензування видів господарської діяльності : Закон України від 02.03.2015 № 222-VIII. URL: https://zakon.rada.gov.ua/laws/show/222-19\#n140 (дата звернення: 27.12.2019 p.).

8. Про Кабінет Міністрів України : Закон України від 27.02.2014 № 794-VII. URL: https://zakon.rada.gov.ua/laws/show/794-18 (дата звернення: 26.12 .2019 p.).

9. Про затвердження Державної стратегії реалізації державної політики забезпечення населення лікарськими засобами на період до 2025 року : постанова КМ України від 05.12.2018 № 1022. URL: https://zakon.rada.gov.ua/laws/show/1022-2018-\%D0\%BF (дата звернення: 27.12.2019р.).

10. Про затвердження Ліцензійних умов провадження господарської діяльності з виробництва лікарських засобів, оптової та роздрібної торгівлі лікарськими засобами, імпорту лікарських засобів (крім активних фармацевтичних інгредієнтів) : постанова Кабінету Міністрів України від 30.11.2016 № 929. URL: https://zakon.rada.gov.ua/laws/show/929-2016-\%D0\%BF/ed20180602 (дата звернення: 26.12.2019 р.).

11. Про затвердження Положення про Міністерство охорони здоров’я України : постанова Кабінету Міністрів України від 25.03.2015 № 267. URL: https://zakon.rada.gov.ua/laws/show/ 267-2015-\%D0\%BF/ed20191226 (дата звернення: 26.12.2019 р.).

12. Про затвердження Порядку проведення галузевої атестації лабораторій з контролю якості та безпеки лікарських засобів : наказ MO3 України від 14.01.2004 № 10. URL: https://zakon.rada.gov.ua/laws/show/z0130-04 (дата звернення: 27.12.2019 p.).

13. Про затвердження Порядку сертифікації якості лікарських засобів для міжнародної торгівлі та підтвердження для активних фармацевтичних інгредієнтів, що експортуються : наказ МО3 України від 07.12.2012 № 1008. URL: https://zakon.rada.gov.ua/laws/show/z2218-12 (дата звернення: 27.12.2019 р.).

14. Про затвердження Порядку контролю якості лікарських засобів під час оптової та роздрібної торгівлі : наказ МО3 України 29.09.2014 № 677. URL: https://zakon.rada.gov.ua/laws/show/ z1515-14 (дата звернення: 26.12.2019 р.).

15. Про затвердження Положення про Державну службу України з лікарських засобів та контролю за наркотиками : постанова Кабінету Міністрів України від 12.08.2015 № 647. URL: https://zakon.rada.gov.ua/laws/show/647-2015-\%D0\%BF (дата звернення: 27.12.2019 p.).

16. Державна служба України 3 лікарських засобів та контролю за наркотиками : державнi реєстри. URL: http://dls.gov.ua/\%d0\%b4\%d0\%b5\%d1\%80\%d0\%b6\%d0\%b0\% d0\%b2\%d0\%bd\%d1\%96-\%d1\%80\%d0\%b5\%d1\%94\%d1\%81\%d1\%82\%d1\%80\%d0\%b8/ (дата звернення: 26.12.2019 р.).

17. Про затвердження переліку органів ліцензування та визначення такими, що втратили чинність, деяких постанов Кабінету Міністрів України : постанова Кабінету Міністрів України від 05.08.2015 № 609. Дата оновлення: 01.02.2020. URL: https://zakon.rada.gov.ua/laws/show/ 609-2015-\%D0\%BF (дата звернення: 26.12.2019 р.).

18. Про Антимонопольний комітет України : Закон України від 26.11.1993 № 3659-XII. Дата оновлення: 02.08.2017. URL: https://zakon.rada.gov.ua/laws/show/3659-12 (дата звернення: 27.12.2019 p.). 